\title{
Teaching and Learning in the Inclusive Classroom: What Foundation Phase Teachers Do?
}

\author{
Jacomina Motitswe \\ Department of Inclusive Education \\ University of South Africa (UNISA), \\ PO Box 392 Pretoria 0003 \\ motitjmc@unisa.ac.za \\ Matseliso L. Mokhele \\ Department of Curriculum and Instructional Studies, \\ University of South Africa (UNISA), \\ PO Box 392 Pretoria 0003 \\ mokheml@unisa.ac.za
}

Doi:10.5901/mjss.2013.v4n6p545

\begin{abstract}
The South African government introduced full service schools to provide quality education to all learners through flexibility to meet the full range of learning needs. Full service schools are institutions that strive to transform themselves, proactively addressing the barriers to learning and increasing participation of the learners and educators in the teaching and learning process. This can be achieved by enhancing the flexibility of teaching and learning methods used. This study, therefore, focused on the teaching and learning methods used in inclusive classrooms to accommodate diversity. This is a case study that was conducted at Mphuphuthe full service school at Ledig village, situated in the Bojanala region in the North West province. A qualitative approach and purposive sampling were used. Based on the data collected, we conclude that a conducive classroom environment, proper classroom organisation, resources, excellent teaching methods and the knowledge of others, in this case (the educators as well as the peers), are assets to learners who experience barriers to learning.
\end{abstract}

Keywords: Diversity, nclusion, differentiation, full-service schools, barriers to learning

\section{Introduction}

In writing that, "Behind each classroom door lies a world of diversity", Lewis and Doorlag, (2006:5) meant that in any classroom learners display differences in their use of language, learning styles, developmental levels, cultures, socioeconomic backgrounds and types of intelligence. This diversity gave rise to the concept of barriers to learning and development, and research has revealed that learners learn in different ways because of hereditary factors, experience, environment and/or their personalities (UNICEF, 2010: http://www.unicef.org/teaches /forum /0301htm). Consequently, the educators need to use a variety of teaching methods and activities to meet, inclusively, the different learning needs of children.

Inclusivity is now a global phenomenon, having received much impetus at the World Conference on Special Needs Education in 1994 in Salamanca, Spain (UNESCO, 1994:7). Its purpose is to inform and guide action by governments, international organisations, national aid agencies, non-governmental organisations (NGOs) and other bodies in implementing the Salamanca Statement on Principles, Policy and Practice in Special Needs Education. Although this was the focus, its conclusion was that it could not advance in isolation, and therefore promoted a broader approach, namely that of Inclusive Education. The new goal was to further the objective of education as a fundamental human right by paying attention to the basic policy shifts necessary for its development, thereby enabling schools to serve all learners, particularly those with special educational needs (UNESCO, 2009:8).

The Salamanca Statement acknowledged the process of strengthening the capacity of education systems that would recognise and respond effectively to diversity. The emphasis was therefore on developing inclusive education systems that would accommodate all learners, regardless of their physical, intellectual, social, emotional, linguistic or 
other conditions. This included both disabled and gifted children. In a South African context inclusive education is defined by the Department of Education (DoE) as a process of addressing the diverse needs of all learners by reducing barriers to and within the learning environment (South Africa, 2005b:12). Policy requires schools to respond to the diversity of learners and to provide equal educational opportunities for all. With regard to learners who experience barriers to learning, a policy of educational equity logically implies enriching the regular education taking place in the classroom with appropriate learning support.

\section{Literature review - Inclusion of all learners}

The philosophy of inclusion in the South African education system is rooted in the country's Constitution ( South Africa, 1996a), which itself is grounded in the values of human dignity, the achievement of equality and the advancement of human rights and freedom (South African Schools Act (SASA, 1996b:34). For that reason, the move towards inclusion in the country's education system has been aimed at maximising the participation of all learners in the curriculum and developing them to become fully functioning citizens who can participate meaningfully in the country's economy, and be able to compete globally. The DoE (South Africa, 1997) defines curriculum as everything that influences the learner, from the educator and work programmes to the environment in which teaching and learning is taking place. According to the Salamanca Statement (UNESCO, 1994:59), inclusion was the guiding principle that informs the framework (which accompanies the statement) that schools should accommodate all learners regardless of their physical, intellectual, social, emotional, linguistic or other conditions. This should include learners with disabilities and gifted learners, street and working learners, and learners from remote or nomadic populations.

This view, according to Mastropieri and Scruggs (2007:46), came to ground diversity as a major feature of classrooms in the 21st century, and reflected a "salad bowl" of multilingual and multicultural society. The analogy of a salad bowl is different from that of the more traditional "melting pot", where all the different ingredients assimilate into "oneness", in that the ingredients contribute to the goodness of the dish without losing their characteristic features. Therefore, the focus of inclusion should no longer be on the "specialness" of the learner and/or the education they need, but rather on increasing participation by the removal of barriers to learning in order for the learners to reach their full potential (Bornman \& Rose, 2010:52). Lorenz (2002:35) also defines inclusion as celebrating the diversity, responding to the acceptance of individual differences and building on their strengths to ensure full participation of all learners in the education system. Following the Salamanca Statement (UNESCO 1994:59) on the definition of inclusion, the DoE initiated the implementation of full service schools to promote inclusion, but if really committed to achieving inclusion of all learners into mainstream schools it had to define a set of principles and more practical aspects to guide the transition process to inclusive education.

\subsection{Why inclusion?}

Swart and Pettipher (2005:19) wrote that the concept of inclusion embraces the democratic values of liberty, equality and human rights, and recognises and accommodates diversity, thereby respecting the rights of all learners. This definition is in line with the South African approach to inclusion defined in White Paper 6 (South Africa, 2001:6), as changes in attitudes, behaviour, teaching methodologies, curricula and environment to meet the diverse needs of all learners. The education system should, therefore, be transformed if it is to respond to the needs of all the learners, but the effective implementation of inclusive education goes beyond ideals and policies. Amongst other things, it requires training and retraining of educators, and they should also feel supported in their efforts to promote learner success and positive interdependence in the classroom. To understand the challenge, specifically in terms of full service schools, it is necessary to examine their development and the practical difficulties facing inclusion in the South African education system.

\subsection{Inclusive policy}

Policies play a valuable role in schools in providing guidelines for actions and procedures and can be public statements that ensure accountability and provide the rationale and framework for change (Walton, 2006:68). Having a specific policy may be necessary to secure inclusion within the school's development plan (Hall, 2002:32) and ensure the implementation of inclusive practice. Such a policy could include the school's aims, practice, and provision for learners who experience barriers to learning. Lazarus, Daniels and Engelbrecht (2004:46-67) concur that the inclusive policy 
should reflect the values and principles of inclusion, for example, answering the question whether the development plan of the school includes aspects that will facilitate the development of an inclusive teaching and learning environment. Inclusive policy should thus promote the development of a barrier-free teaching and learning environment that accommodates the diverse needs of all learners.

Ainscow (1999:192) argues that an inclusive policy should describe the basic values and principles which form the basis of all further planning, and from which a clear vision can be derived. The composition and implementation of inclusive education was viewed as the point of departure regarding planning in the full service school. Westhood (1998:3) is also of the opinion that a policy should contain a view of the future, for example, taking into account what the school wanted and then formulating it as a clear vision. The inclusive policy should foster the personal, academic and professional development of all learners in the school. This can be done by developing the learners in totality, including the personal, emotional, social and academic dimensions.

To advocate the development of an inclusive teaching and learning environment, Lorenz (2002:109) stresses that everyone in the school should be involved in the composition or adaptation of an existing school policy if it is to become inclusive. For Ainscow (1999:192), the whole school community should have a part to play, as policy would only influence practice if all those involved had ownership of the process. From this it can be concluded that all roleplayers should be involved to support both the educators and learners in promoting inclusion of all learners. To ensure that all educators of the full service school take responsibility to support all learners, Daniels, Norwich and Anghlilen (1993:169) and Lorenz (2002:110) recommend that an inclusive policy should provide basic information about the school's expectations of how to address diversity and provide support to learners who experience barriers to learning. This could include information about the school's policies for identification assessment of and support for learners who experience barriers to learning. Therefore, it becomes clear that an inclusive policy should provide a framework for enhancing the learning and participation of all learners (Rogers, 1996:26).

Considering that much learning and teaching take place through the medium of language, and that language forms part of all spheres of human interaction and development, language has become a central component in addressing the development of full-service schools (South Africa, 2005b:18). The inclusive policy should, therefore, ensure that language needs of all learners in the school are met, primarily as an integral part of the curriculum.

\section{Research methodology}

A case study was used to investigate the teaching and learning methods in inclusive classrooms in the foundation phase. Creswell (2003:15) describes a case study as a way in which the researcher explores a programme in-depth, or an event, activity or one or more individuals. De Vos et al. (2005:272) concurs that it aims to gain an in-depth understanding of a practice or issues to facilitate informed decision-making, for example, it examines a "bounded" (single) entity or phenomenon, over a specific time. We therefore sought to gain an in-depth understanding of the case study, of what is done in the inclusive classrooms, to address external barriers to learning in order to accommodate all learners. The research participants were one foundation phase HOD and six educators.

\section{Findings and discussions}

This section captures the content taught, methods of teaching and learning and the concluding remarks.

\subsection{Content (what is taught)}

For a classroom to be fully inclusive, educators need to make sure that the curriculum is accessible and relevant to all learners in terms of what is taught (content); how the educators teach it; how the learners learn best (process); and how it relates to the environment in which the learners are living and learning (UNESCO, 2005:20). According to the reports from all the respondents, it is indicated that they are flexible in their approaches of teaching and in the activities they give the learners. The respondents said that they considered the learners' level of ability and gave them different activities. They also spoke at length about differentiated lesson planning and differentiated teaching, whereby scaffolding of activities is done so that they can differ according to the learners' abilities, as shown by the differentiated lesson plans:

We use differentiated lesson planning. the differentiated lesson planning assist in the case of the learner who experiences barriers to learning, when we are busy with the other learners, it indicate what the learner with barriers to 
learning will be doing"; "But we as educators, we create many activities to accommodate every learner in the classroom"; "What we are doing is that every learner is provided with activities that are of his/her level and assessed on them". Hence there is differentiated and individual planning.

According to the data and the observations, more emphasis is put on listening and reading in Grade 1 . The respondents gave the reason that most of the learners were unfamiliar with the LOLT, which was Setswana. It was observed that they followed the milestones as set out by the foundations for learning for all the learning programmes, but they implemented them inclusively to accommodate all the learners.

The milestones for literacy are as follows:

\subsubsection{Listening and speaking}

Oral presentation: whereby the learners tell their own stories of what they did the previous day or before coming to school. In Grade 1, learners were given the chance to tell their stories to the whole class. In Grade 3 they shared their stories in groups or pairs, with one learner retelling what the previous one had said.

\subsubsection{Shared reading}

Both grades were observed using 'big books' for shared reading, the contents of which differed according to the grades. The Grade 1 'big book' had limited text but many pictures, for example different farm animals performing different actions. The example of the text was: kgogo (a hen). Kgogo e beela mae (a hen is laying eggs); Kgomo (a cow). Kgomo e nwa metsi (the cow is drinking water). The activities the Grade 1 learners were given on the shared reading differed according to their level of ability. One group was given an activity of cutting out pictures of different farm animals and writing their names; one group was supposed to write a name for each picture; another to fill in the missing letter/s to complete the name of the animal in the picture, for example: $\mathrm{kg}_{-} \mathrm{m}_{-}$; another to cutting out all the animals and paste it next to the correct name. The educators also introduced songs and rhymes about the animals. It was observed that most of the learners enjoyed the lesson.

\subsubsection{The 'big book'}

The theme was on fruit and vegetables. There was much text (a paragraph). The educator first discussed with the learners the pictures, and then read the text to the learners and later with them. The educator then gave one group an activity to write a paragraph on any fruit or vegetable they liked and why; the other group was given an activity on differentiating the pictures according to fruit and vegetables; the other group was given an activity to write a sentence on given words of fruit and vegetables; the other group was supposed to cut and paste different fruit and vegetables and to write their names.

\subsubsection{Sounds and phonics}

The researcher observed that a letter was taken from the shared reading text to teach sound and phonics.

Grade 1: The "kg" sound was taught for the whole week, but using different activities. The educator introduced the sound by giving a sentence with a repeated sound in it, for example: dikgomo tsa kgosi di kgaotse dikgole tsa rakgadi. The educator repeated the sentence several times by using pictures and gestures and asked the learners to identify the repeated sound they heard. The learners identified the "kg" sound. One briliant learner instead identified the "di" sound, but this was not wrong because the "di" sound was also repeated several times. The educator praised that learner because he/she was very observant, but then told the learners that they were going to learn the " $\mathrm{kg}$ " sound. The learners were requested to give all the words they know which had the "-kg" sound. The educator wrote them on the chalkboard as they learners gave them, kgomo (cow); kgamelo (bucket); kgole; (rope); nkga (smell). The educator read the words with the learners and later allowed them to read them alone. They were given homework to cut out pictures of all the words with the "kg" sound. The learners were given activities to write a word for each picture; another group was given an activity to fill in the missing letter; another of writing a simple sentence using the words given; another of tracing on the dotted words given. 
The learners were asked to identify a sound that appeared repeatedly in the text from the 'big book' in Grade 3. It was a "th" sound. The learners were then requested to write all the words starting with the "th" sound, thapi (fish); thaga (grass); thhogo (head); thhothhora (wipe); thholego (nature); thasela (attack), after which they were asked to read the words several times. The educator gave each group an activity to do, with one group to write a sentence with a repeated sound in it; another to write sentences using the words given; another to match pictures with words; the other to fill in the missing words to complete a sentence. These were only a few of the activities and milestones carried out and observed in Grades 1 and 3. Most of the activities, especially in Numeracy and Life Skills were done practically. For example, for oral counting learners were using abacuses and other objects to count. For problem solving activities, they were involved practically for example in the Grade 3 classroom they were solving problems on measurement, and the educator allowed them to use different measuring instruments, such as a cup and bottles with different sizes. The same applied to the Grade 1 learners, who were learning in a 'fun' way.

Bornman and Rose (2010:75) argue that when planning a differentiated teaching lesson, the content of the instruction should include the same broad concept, principles and skills for all learners, for instance, in the example of teaching the "-kg" sound, learners were given different activities, but the main content was on the sound. Another example was on storytelling about farm animals. The educator told the story using facial expressions and gestures, and varied the tone of her voice. The learners were enjoying the story and could even dramatise it. Different activities were given from the story, with some learners having an activity to cut out all the animals mentioned in the story; others were matching the animals with their homes; others making sounds of different animals and the others saying which animal it was. From the story itself, learners were taught different things, such as the sounds of animals, where they lived, what they fed on, and how they could help people.

\title{
4.2 Methods of teaching and learning
}

Regarding teaching methods, the respondents indicated that they were using different ones, particularly multi-level teaching because they were aware that learners differed according to their level of ability: "We use different types of methods. We use multi-level teaching because learners vary according to their level of ability." The DoE (South Africa, 2005e:67) states that in applying teaching methods educators should bear in mind that there is no single classroom in which all learners will be exactly the same or learn in the same way and at the same pace. As a result, they were required to be creative in the use of a variety of teaching methods to reach all the learners. The respondents identified different methods that they were using to teach in inclusive classrooms, such as storytelling, songs, rhymes, dramatisation, learning through play as well as questions and answers:

\begin{abstract}
We also use storytelling, whereby an educator tells a story, using pictures and a big book for that matter, and we also allow the learners to retell the story and also dramatise it"; "Some learners learn best through songs; others like rhymes; and others can understand and cope by listening while the educator is teaching"; "Some can even formulate a game from an activity, especially in Numeracy, when they count. The learners grasp a lot as they play. It is learning through play".
\end{abstract}

Teaching through songs, rhymes, dance, poems, and acting is a lot of fun. For educators this means that when they are planning lessons they need to use visual materials (such as posters, pictures, drawings); to use tasks that involve discussion (listening and speaking); and to provide opportunities for movement of some form (eg drama and dance). The respondents added that they accommodated all the learners' learning needs and styles of learning: "Some learners learn best through songs; others like rhymes; and others can understand and cope by listening while the educator is teaching. So we use songs, rhymes, colorful pictures and real objects when we teach." They said that they usually used gestures, and body and facial expression when they taught so that the learners would better understand.

The respondents added:

We also use co-operative learning so that learners can work together, especially in solving problems, in making projects and in reading"; "We include learners who are good in each group so that they can assist those who experience barriers to learning. Learners are free to share ideas and to interact with each other.

Co-operative learning occurs when learners share responsibility and resources, as well as when they work towards common goals. According to what was observed, the respondents were using cooperative learning properly because they usually explained the instructions to the groups and provided guidelines and resources needed to do the 
activity or project, while they would just facilitate and guide the groups: "As educators, we walk around to guide them and facilitate and also to control discipline". They served as facilitators who provided the right environment and opportunity for all to learn actively. The respondents stated that they also use individualised and group work: "When we group the learners; we put them in a circle group of six"; "We involve them all by giving them group activities, and the activities we give them vary according to the groups and level of ability so that they can all participate". They added that the learners liked to work in groups and all participate. One respondent indicated that in order to involve all the learners in the group work she used to give each a responsibility for the same activity: "We try to give each one an activity based on the topic of the course, so that everyone can participate fully".

The respondents emphasised that they just facilitated the group so that the work could be done: "Most of the times, the learners are the ones who are fully involved in the lessons and activities; we just facilitate and guide them, and also provide support". This statement indicates that the approach of teaching used was learner-centred. It was observed that the respondents taught some of the learners on a one-to-one basis, which is individualised teaching. They said that they would scaffold the activities for those individual learners so that they would be able to attain the necessary skills and knowledge. The respondents stated that they also allowed learners to use the methods they preferred so that they could learn effectively: "We also allow learners to use the method of their choice in order to learn effectively". According to the researchers' observation, the respondents are dedicated at their work and try by all means to include all the learners in teaching and learning".

\section{Conclusion}

The data analysis indicated that the classroom environment, classroom organisation, resources, teaching methods and the knowledge of others, in this case, the educators as well as the peers are assets to learners who experience barriers to learning. That means the educators made sure that all learners should be accommodated in teaching and learning. Differentiated teaching, scaffolding of assessment standards, lesson plans and activities were provided to accommodate the diverse learning needs of all learners. Even if the development of full service schools is still a working process in South Africa, the findings indicate that teaching and learning addresses diversity.

\section{References}

Ainscow, M. 1999. Understanding the development of inclusive schools. London: Falmer.

Bornman, J. \& Rose, J. 2010. Believe that all can achieve: increasing classroom participation in learners with special support needs. Pretoria: Van Schaik.

Creswell, JW. 2003. Research design: qualitative and quantitative approaches. Thousand Oaks,CA: Sage.

Daniels, H, Norwich, B \& Anghlilen, N. 1993. Teacher support teams: an evaluation of a school-based approach to meeting special education needs. Support for learning. (4): 169-173.

De Vos, AS, Strydom, H, Fouche, CB \& Delport, CSL. 2005. Research at grassroots. 3rd edition. Pretoria: Van Schaik.

Hall, R. 2002. Implementing inclusive educational practices through partnership. South African Journal of Higher Education. 16(3): 31 38.

Lazarus, S, Daniels, B \& Engelbrecht, L. 2004. Inclusive schools, in Engelbrecht, P; Green, L; Naicker, S. \& Engelbrecht, L (eds). 2007. Inclusive education in action in South Africa. Pretoria: Van Schaik.

Lewis, RB \& Doorlag, D. 2006. Teaching special students in general education classroom. Upper Saddle River, NJ:Pearson.

Lorenz. S. 2002. First steps in inclusion: a handbook for parents, teachers, governors and local education authorities. London: Fulton. Mastropieri, MA \& Scruggs, TE. 2007. The inclusive classroom: strategies for effective instruction. 3rd edition. Columbus: Merrill.

Rogers, R. 1996. Developing an inclusive policy for your school. Bristol: CSIE.

South Africa. 1996a. The South African Constitution and Bill of Rights. Pretoria: Government Printer.

South Africa. 1996b. South African Schools Act 84 of 1996. Pretoria: Government Printer.

South African Department of Education. 1997. South African quality education for all. Pretoria: Government Printer.

South African Department of Education. 2001. Education White Paper 6: special needs education. Building an inclusive education and training system. Pretoria: Government Printer.

South African Department of Education. 2005b. Conceptual and operational guidelines for the implementation of inclusive education: full service schools. Pretoria: Government Printer.

South African Department of Education. 2005e. Guidelines for inclusive learning programmes. Pretoria: Government Printer.

Swart, E \& Pettipher, R. 2005. A framework for understanding inclusion in E, Landsberg, E, Krüger,

D \& Swart, E (eds.). Addressing barriers to learning: a South African perspective. Pretoria: Van Schaik.

Unesco. 1994. The Salamanca statement and framework for action on special needs education. Paris: Unesco.

Unesco. 2005. Understanding and responding to children's needs in inclusive classrooms: a guide for the teachers. Paris: Unesco. 
Unicef. 2010. Multiple ways of teaching and learning in Bangladesh. Available at: http://www.unicef.org/teaches/forum /0301htm 06. [Date accesses 30 April 2013]

Walton, EL. 2006. The role of education managers in implementing a policy of inclusion in independent Christian schools. Pretoria: University of South Africa.

Westwood, P. 1998. Common sense methods for children with special needs. London: Routledge. 
